\title{
Sistem Pengaduan Layanan Akademik Menggunakan Responsive Web Design
}

\author{
Yayuk Ike Melani \\ Sistem Informasi, STMIK PalComTech \\ Jl. Basuki Rahmat No. 05 Palembang \\ Yayuk_ike@palcomtech.ac.id
}

\begin{abstract}
Abstrak-Sistem pengaduan layanan akademik yang ada pada STMIK PalComTech menggunakan kuesioner yang diberikan kepada mahasiswa setiap bulannya sehingga mahasiswa terkadang lupa untuk menyampaikan keluhan apa saja yang akan diberikan. Kuesioner hanya ditujukan kepada layanan konsumen, layanan dosen dan layanan BAAK. Belum tersedianya sistem pengaduan untuk Sarana dan Prasarana serta Keuangan. Penelitian ini bertujuan untuk merancang sebuah sistem pengaduan layanan akademik yang ditujukan kepada mahasiswa untuk mempermudah mahasiswa dalam menyampaikan keluhannya terhadap layanan akademik setiap saat tanpa harus menunggu satu bulan untuk menyampaikan keluhan. Dalam pengembangannya sistem ini menggunakan metode waterfall sedangkan desain dari sistem menggunakan responsive web desain yang dapat dibuka melalui komputer desktop atau handphone. Hasil dari penelitian ini adalah sebuah aplikasi yang digunakan sebagai sistem monitoring kepuasan mahasiswa terhadap layanan akademik yang diberikan oleh BAAK, Keuangan dan Sarpras serta memberikan hak kepada mahasiswa untuk dapat menyampaikan keluhannya kepada pihak layanan akademik melalui media yang telah disediakan.
\end{abstract}

Kata Kunci-Pengaduan, Mahasiswa, Waterfall

\section{PENDAhUluan}

Pengaduan adalah laporan yang mengandung informasi atau indikasi terjadinya pelanggaran terhadap kode etik dan pedoman perilaku hakim, pelanggaran kode etik dan pedoman perilaku panitera dan jursita, pelanggaran terhadap kode etik dan kode perilaku pegawai Aparatur Sipil Negara, pelanggaran hokum acara atau pelanggaran terhadap disiplin pegawai negeri sipil atau peraturan disiplin militer, maladministrasi dan pelayan publik dan/atau pelanggaran pengelolaan keuangan dan barang milik negara.

STMIK PalComTech adalah salah satu perguruan tinggi swasta yang ada di Palembang. Mahasiswa yang dimiliki oleh STMIK PalComTech kurang lebih ada sekitar 634 mahasiswa yang terbagi menjadi dua jurusan yaitu Sistem Informasi dan Teknik Informatika. Dengan banyaknya mahasiswa, mendorong perguruan tinggi untuk meningkatkan kualitas perguruan tinggi. Salah satu kualitas yang perlu ditingkatkan adalah kualitas layanan akademik bagi mahasiswa. Layanan akademik terdiri dari layanan BAAK, layanan keuangan dan layanan Sarana dan Prasarana atau Sarpras.

Dalam melaksanakan tugasnya, seringkali BAAK mendapatkan kritikan yaitu ketidakpuasan mahasiswa terhadap layanan yang diberikan BAAK kepada mahasiswa. Pelayanan yang kurang maksimal memberikan efek kekecewaan kepada mahasiswa. Biasanya keluhan atau pengaduan terhadap layanan BAAK dapat disalurkan melalui kuesioner yang diadakan satu bulan sekali. Kuesioner ini tidak banyak menampung aspirasi dan keluhan pelayanan BAAK terhadap mahasiswa karena mahasiswa kebanyakan lupa akan hal apa saja yang akan dikeluhkan dan diminta untuk diperbaiki layanannya.

Keluhan mahasiswa ini tidak hanya diberikan kepada devisi BAAK saja, namun devisi keuangan dan sarana dan prasarana pun juga sering kali mendapat keluhan dari mahasiswa. Keuangan adala kebutuhan-kebutuhan yang terkait masalah uang yang dipetakan dengan tujuan untuk mengetahui jumlah keluar masuknya uang yang ada dilembaga tersebut [1]. Keuangan adalah salah satu devisi yang ada di STMIK PalComTech. Keuangan berkaitan dengan pembayaran mahasiswa seperti pembayaran SPP, SKS per matakuliah dan lain sebagainya. Dalam menjalankan tugasnya, keuangan juga mendapatkan kritikan dari beberapa mahasiswa. Kritikannya bisa bermacam-macam berkaitan dengan keuangan. Tidak hanya devisi keuangan, ada juga devisi sarpras yang tidak luput dari kritikan.

Berdasarkan latar belakang yang telah dikemukakan, maka diperlukannya sebuah sistem penunjang yang berfungsi sebagai alat penampung keluhan mahasiswa terhadap BAAK, Keuangan dan Sarpras yang bisa digunakan setiap saat tanpa harus menunggu. Sistem yang akan rancang dan dibangun adalah sebuah aplikasi antarmuka berbasis web yang akan menampung keluhan yang disampaikan oleh mahasiswa baik keluhan terhadap BAAK, Keuangan dan Sarpras yang terkoneksi dengan internet. Keluhan yang diberikan oleh mahasiswa akan berupa laporan yang diberikan kepada pimpinan untuk ditindaklanjuti. Aplikasi ini dibuat bertujuan 
untuk memberikan kesempatan kepada mahasiswa untuk menyampaikan tingkat kepuasannya terhadap layanan akademik yang telah diterima. Tujuan dari penelitian ini adalah membantu mahasiswa dalam menyampaikan pengaduan terhadap layanan akademik agar isntitusi dapat lebih baik lagi.

Penelitian yang berjudul Implementasi Pengembangan Student Information Terminal (S-IT) Untuk Pelayanan Akademik Mahasiswa memaparkan bahwa Pemanfaatan TIK terutama penerapan penggunaan sistem informasi pada bidang layanan administrasi akademik di perguruan tinggi saat ini menjadi suatu kebutuhan wajibsupaya dapat meningkatkan daya saing perguruan tinggi. Student Information Terminal (S-IT) pada perguruan tinggi. SIT sendiri merupakan paket perangkat sistem informasi akademik mahasiswa yang mengkombinasikan hardware, software dan teknologi guna memudahkan pelayanan akademik kepada mahasiswa secara terkomputerisasi pada perguruan tinggi [2]

Penelitian yang berjudul Pengelolaan Sistem Informasi Akademik Perguruan Tinggi Berbasis Teknologi Informasi dan Komunikasi (TIK) memaparkan bahwa Efektivitas aplikasi TIK dalam proses manajemen kelembagaan sering terhambat oleh banyak faktor non teknis yang tidak dipersiapkan lembaga. Mulai dari penyiapan orang, budaya, mekanisme organisasi, bahkan teknis pemeliharaannya. Untuk mencapai Sistem Informasi Akademik yang berjalan efektif, mampu membantu stakeholder internal ataupun eksternal dengan menyediakan informasi yang akurat, cepat, dan cukup, diperlukan sumber daya manusia yang handal. SDM sistem informasi akademik yang handal ditentukan oleh beberapa faktor yaitu budaya TIK positif yang berkembang di konteks SIA itu berada (lingkungan perguruan tinggi), Pendidikan dan Pelatihan SDM, Sistem Reward dan Standar Kompentensi Personel SIA [3].

\section{LANDASAN TEORI}

\section{A. Keluhan}

Keluhan yang diberikan oleh pelanggan dalam pemakaian produk atau jasa merupakan suatu umpan balik dari kualitas produk atau jasa yang digunakan oleh pelanggan. Semakin banyak keluhan yang diberikan oleh pelanggan membutuhkan adanya perhatian ekstra bagi setiap perusahaan yang menerima keluhan untuk memperbaiki dalam pembuatan produk atau jasa [4]

\section{B. Flowchart}

Pengertian flowchart adalah representasi grafik yang menggambarkan setiap langkah yang akan dilakukan dalam suatu proses, yang merupakan alat bantu yang banyak digunakan untuk menggambarkan sistem secara pisikal [5].
Setiap simbol mempunyai fungsi yang berbeda. Simbol digunakan pada diagram alur untuk mewakili fungsi dari sistem pemrosesan informasi. Fungsi-fungsi ini adalah input/output, pemrosesan, aliran data dan anotasi [6]. Adapun simbol-simbol yang digunakan dalam mempresentasikan flowcart ditunjukan pada gambar 1 .

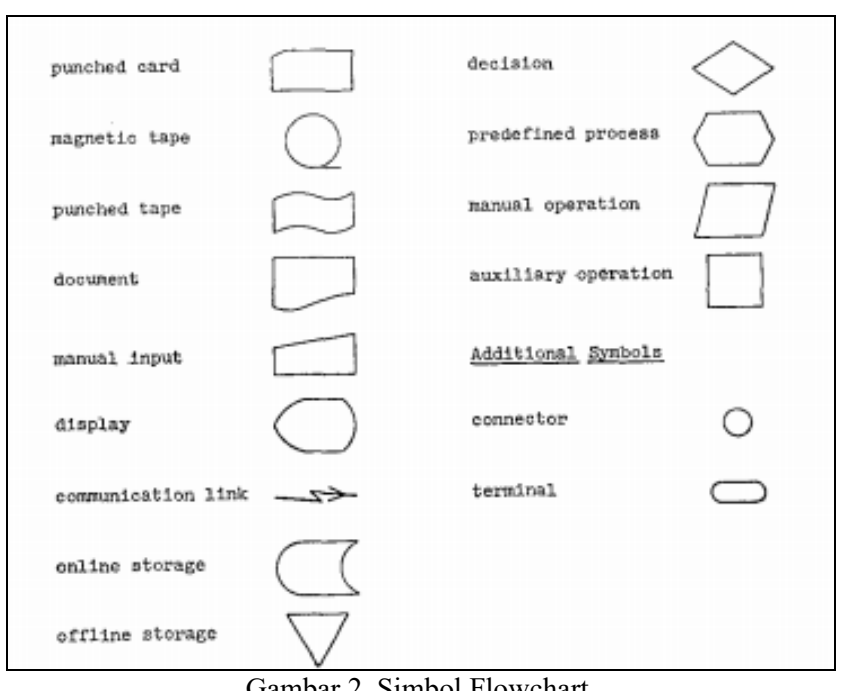

\section{Responsive Web Design}

Responsive web design adalah pendekatan desain web yang dapat beradaptasi dengan masalah pada web browser dan perangkat keras yang menjalankannya untuk menciptakan respon terhadap kebutuhan pengguna [7]. Ada tiga elemen utama dalam teknologi responsive web design yaitu:

1. Tata letak fleksibel berbasis grid

2. Gambar dan media fleksibel

3. Media queries

Web responsive dalam penelitian ini sangat menguntungkan mahasiswa karena aplikasi ini dapat dibuka melalui handphone sehingga mempermudah mahasiswa dalam memberikan keluhan terhadap devisi.

\section{Bootsrap}

Bootstrap merupakan framework CSS, yang menyediakan kumpulan komponen-komponen antarmuka dasar pada web yang telah dirancang sedemikian rupa untuk digunakan bersama-sama [7]. Bootstrap memiliki beberapa fitur yang dapat digunakan, diantaranya:

- css/bootstrap.css berisi style dasar (reset, layout, typography, button) bawaan bootstrap.

- css/bootstrap-responsive.css berisi setting responsive desain. User bisa memakainya bersama bootstrap.css untuk membuat style bootstrap menjadi responsive.

- css/bootstrap-min.css

- css/bootstrap-responsive-min.css versi compressed 
dari bootstrap.css dan bootstrapresponsive.css

- img/glyphicons-halflings.png

- img/glyphicons-halflings-white.png, adalah icon yang digunakan pada bootstrap dengan teknik spriting.

- js/bootstrap.js

- js/bootstrap-min.js adalah javascript untuk mengaktifkan berbagai fitur keren bawaan bootstrap.

\section{Metodologi Penelitian}

Metodologi yang digunakan adalah metode Waterfall. Metode pengembangan sistem sekuensial linier atau yang sering disebut juga dengan siklus kehidupan klasik atau model air terjun (waterfall model) memberikan sebuah pendekatan pengembangan sistem yang sistematik dan sekuensial, dimulai dari fase perencanaan sistem, analisis, desain, kode, pengujian, dan pemeliharaan. Oleh sebab itu, metode ini hampir selalu digunakan untuk pengembangan perangkat lunak terutama di lingkup akademisi khususnya mahasiswa yang sedang menyelesaikan Tugas Akhirnya.Analisa kebutuhan perangkat lunak adalah pengumpulan kebutuhan untuk menspesifikasikan kebutuhan perangkat lunak sehingga dapat dipahami kebutuhan dari user [8]. Dalam metode waterfall terdapat beberapa tahapan yaitu :

\section{A. Analisis Kebutuhan}

Tahap analisis bertitik-tolak pada kegiatan-kegiatan dan tugas-tugas dimana sistem yang berjalan dipelajari lebih mendalam, konsepsi dan usulan dibuat untuk menjadi landasan bagi sistem yang baru yang akan dibangun. Pada akhir tahap ini separuh kegiatan dari usaha pengembangan sistem informasi telah diselesaikan [9]. Tahapan ini dimaksudkan untuk mengetahui sistem yang berjalan seperti apa pada tempat penelitian. Pada tahapan ini, peneliti mendokumentasikannya dengan cara wawancara kepada pemakai sistem sehingga para pemakai sistem akan mengerti bagaimana cara menggunakan system baru serta peneliti dapat mengetahui kebutuhan dan batas kemmapuan dari pemakai sistem.

\section{B. Desain Sistem}

Pada tahapan ini, peneliti memulai mendesain sistem yang sesuai dengan pengguna sistem. Spesifikasi perangkat yang akan digunakan baik perangkat keras maupun perangkat lunak. Tujuan dari tahapan ini untuk memberikan gambaran kepada pengguna sistem bagaimana cara kerja dari sistem yang akan dibuat dan bagaimana tampilannya yang dibuat sesuai dengan kebutuhan dari pengguna. Apabila pengguna sistem setuju dengan gambaran sistem yang dibuat oleh peneliti maka akan dilanjutkan kedalam tahap selanjutnya yaitu implementasi sistem.

\section{Implementasi}

Dalam tahapan ini, peneliti mulai mengimplementasikan desain kedalam sistem yang telah disetujui. Jika system sudah selesai, kemudian peneliti melakukan pengujian sistem kepada pengguna serta mendokumentasikan prosedur-prosedur sistem yang digunakan saat pengoperasian sistem. Memastikan personil yang terlibat dalam pengoperasian sistem baru benarbenar memahami alur sistemnya.

\section{Pengujian Sistem}

Tahapan ini adalah tahapan dimana fungsi-fungsi software diujicobakan agar terbebas dari error dan hasilnya harus sesuai dengan kebutuhan yang telah didefinisikan sebelumnya. Pengguna sistem diminta untuk menggunakan pertama kali sistem yang telah dibuat. Semua proses diujikan mulai dari tahap login aplikasi sampai tahap pengaduan. Selain itu, admin diminta untuk mengecek akses admin apakah pengaduan yang dikirimkan oleh mahasiswa sudah masuk dalam kotak pengaduan atau tidak. Jika masuk admin akan menyaring pengaduan seperti apa yang layak untuk dilaporkan kepada pimpinan.

\section{E. Pemeliharaan}

Tahap ini adalah tahapan terakhir dari metode waterfall yaitu melakukan pemeliharaan terhadap software maupun hardware yang menunjang sistem. Serta memperbaiki jika ada bug atau kesalahan yang tidak ditemukan pada saat tahapan testing.

Semua tahapan yang telah dilakukan terlihat pada gambar 3 berikut :

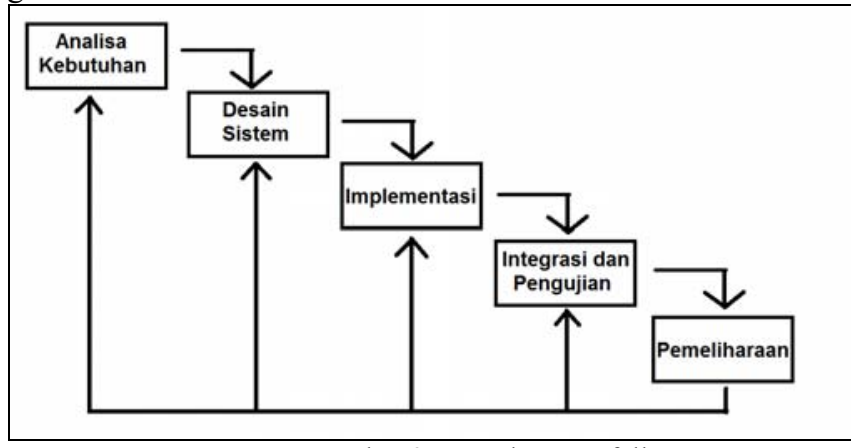

Gambar 3. Metode Waterfall

\section{HASIL DAN PEMBAHASAN}

Hasil dari penelitian ini adalah sebuah website yang menampung keluhan mahasiswa terhadap pelayanan yang diberikan oleh BAAK, Keuangan dan Sarpras. Website ini mempunyai pengguna yaitu mahasiswa dan SPMI. Alur yang berjalan dalam system terlihat pada gambar 4 . 


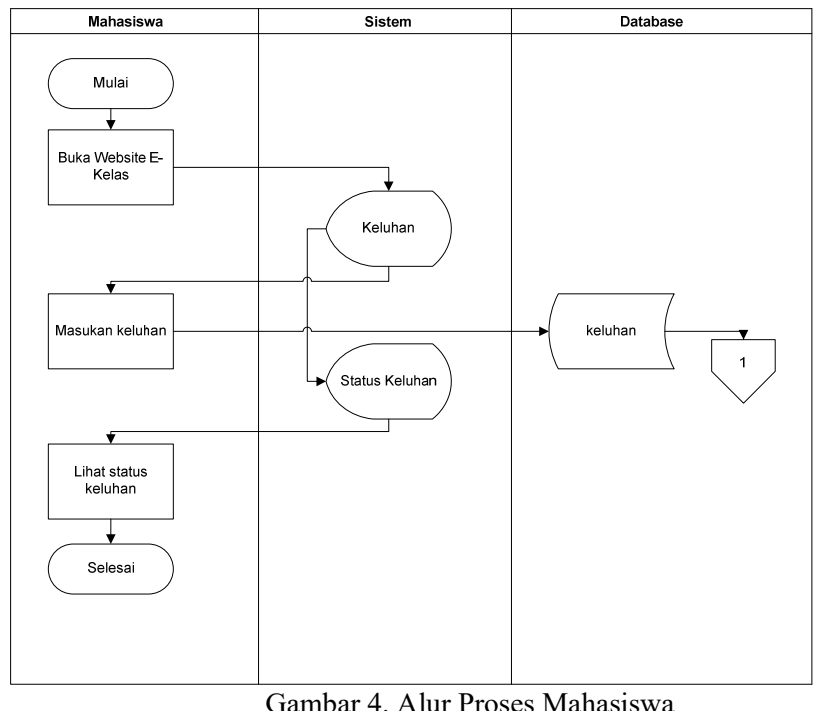

Dalam proses memberikan keluhan, mahasiswa dapat membuka aplikasi yang telah disediakan untuk memberikan keluhan. Dalam aplikasi terdapat 3 pilihan menu yaitu keluhan terhadap BAAK, Keuangan dan Sarpras. Mahasiswa dapat memilih salah satu atau pilih ketiga menu untuk memberikan keluhan. Kemudian data keluhan akan masuk kedalam database aplikasi. Selanjutnya keluhan terhadap ketiga devisi akan diproses oleh SPMI dan diberikan kepada pimpinan hasil keluhan berupa laporan. Alur proses untuk admin terlihat pada gambar 5 .

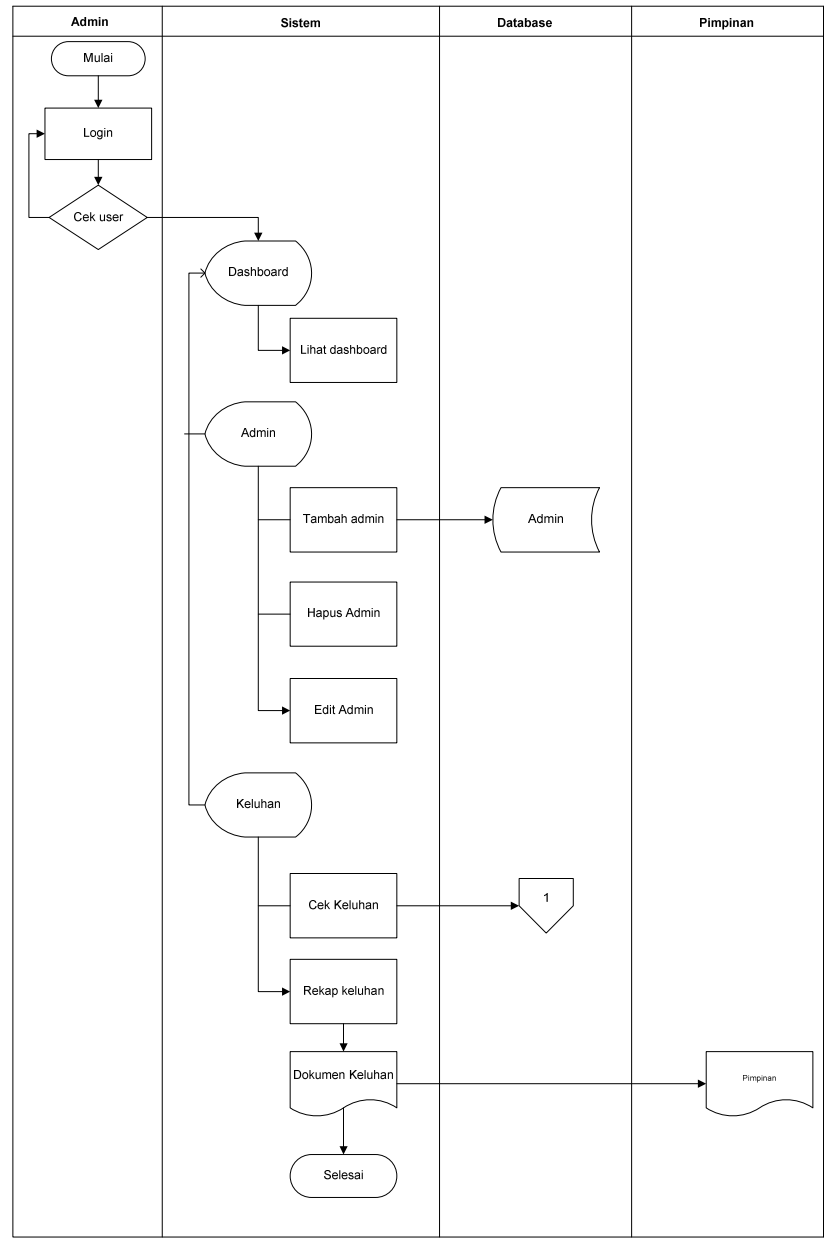

Gambar 5. Alur Proses Admin

SPMI yang berperan sebagai admin akan menerima laporan keluhan yang diberikan oleh mahasiswa. Keluhankeluhan yang diberikan akan dicetak dalam bentuk laporan dan akan diberikan kepada pimpinan yang akan selanjutnya akan ditindaklanjuti oleh pimpinan.

\section{A. Implementasi Sistem}

1) Tampilan Interface Awal

Tampilan interface awal pada aplikasi ini adalah tampilan halaman awal yang menampilkan menu-menu pilihan bagi mahasiswa yang ingin memberikan keluhan. Menu-menu pilihan yang ditampilkan adalah menu keluhan terhadap BAAK, menu keluhan terhadap keuangan dan menu keluhan terhadap sarpras. Mahasiswa boleh memilih saah satu atau lebih untuk memberikan keluhan terhadap divisi masingmasing. Menu tampilan untuk keluhan terlihat pada gambar 6 . 


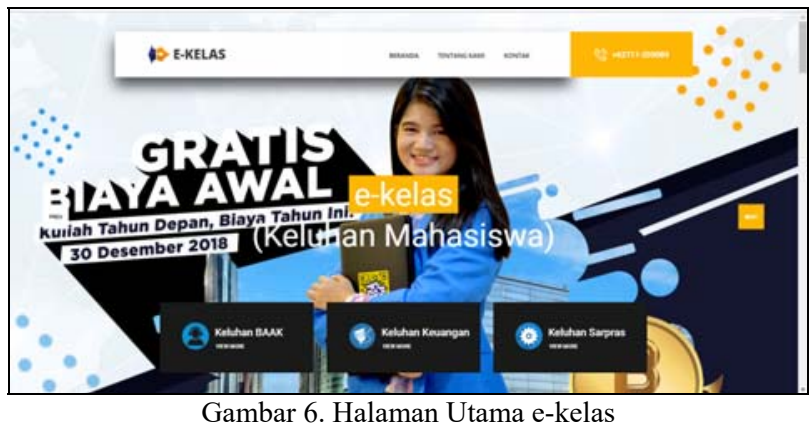

2) Tampilan Interface Menu Keluhan BAAK

Tampilan interface menu keluhan BAAK pada aplikasi ini adalah tampilan halaman yang menampilkan halaman input keluhan bagi mahasiswa. Pada halaman ini mahasiswa bebas memberikan keluhannya terhadap devisi BAAK. Pada halaman ini mahasiswa wajib mengisi field-field yang ada pada form. Field-field yang diisi antara lain tanggal yaitu tanggal berapa mahasiswa memberikan keluhannya, jurusan diisi sesua dengan jurusan mahasiswa, perihal yaitu keluhan tentang apa yang akan diberikan oleh mahasiswa, dan terakhir adalah menu deskripsi keluhan yang merupakan uraian dari keluhan mahasiwa. Keluhan yang diberikan oleh mahasiswa akan diterima oleh admin dari aplikasi. Menu tampilan untuk keluhan terhadap BAAK terlihat pada gambar 7.

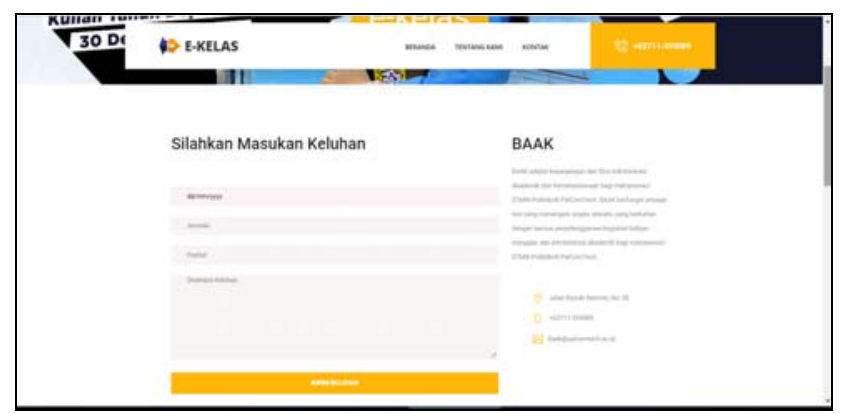

Gambar 7. Tampilan Menu Keluhan Terhadap BAAK

3) Tampilan Interface Menu Keluhan Keuangan

Tampilan interface menu keluhan keuangan pada aplikasi ini adalah tampilan halaman yang menampilkan halaman input keluhan keuangan bagi mahasiswa. Pada halaman ini mahasiswa bebas memberikan keluhannya terhadap divisi keuangan. Macam-macam keluhan yang dapat diutaran oleh mahasiswa dapat berupa keluhan terhadap pembayaran kuliah dan lain sebagainya.

Pada halaman ini mahasiswa wajib mengisi field-field yang ada pada form. Field-field yang diisi antara lain tanggal yaitu tanggal berapa mahasiswa memberikan keluhannya, jurusan diisi sesua dengan jurusan mahasiswa, perihal yaitu keluhan tentang apa yang akan diberikan oleh mahasiswa, dan terakhir adalah menu deskripsi keluhan yang merupakan uraian dari keluhan mahasiwa. Keluhan yang diberikan oleh mahasiswa akan diterima oleh admin dari aplikasi. Menu tampilan untuk keluhan terhadap keuangan terlihat pada gambar 8 .

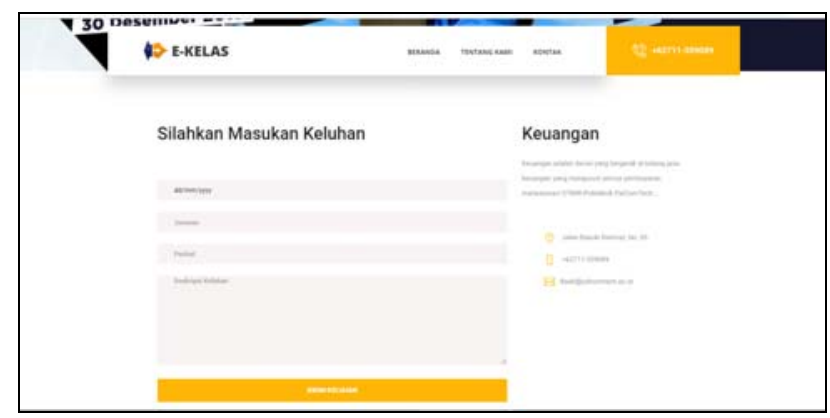

Gambar 8. Tampilan Menu Keluhan Terhadap Keuangan

\section{4) Tampilan Interface Menu Keluhan Sarpras}

Tampilan interface menu keluhan sarpras pada aplikasi ini adalah tampilan halaman yang menampilkan halaman input keluhan sarpras bagi mahasiswa. Pada halaman ini mahasiswa bebas memberikan keluhannya terhadap divisi sarpras. Keluhan yang dapat diutarakan kepada devisi sarpras adalah keluhan yang berkaitan dengan divisi tersebut. Keluhan dapat berupa keluahan terhadap fasilitas gedung, keluhan terhadap internet yang digunakan dan keluhan lain-lainnya. Pada halaman ini mahasiswa wajib mengisi field-field yang ada pada form. Field-field yang diisi antara lain tanggal yaitu tanggal berapa mahasiswa memberikan keluhannya, jurusan diisi sesua dengan jurusan mahasiswa, perihal yaitu keluhan tentang apa yang akan diberikan oleh mahasiswa, dan terakhir adalah menu deskripsi keluhan yang merupakan uraian dari keluhan mahasiwa. Keluhan yang diberikan oleh mahasiswa akan diterima oleh admin dari aplikasi. Menu tampilan untuk keluhan terhadap sarpras terlihat pada gambar 9.

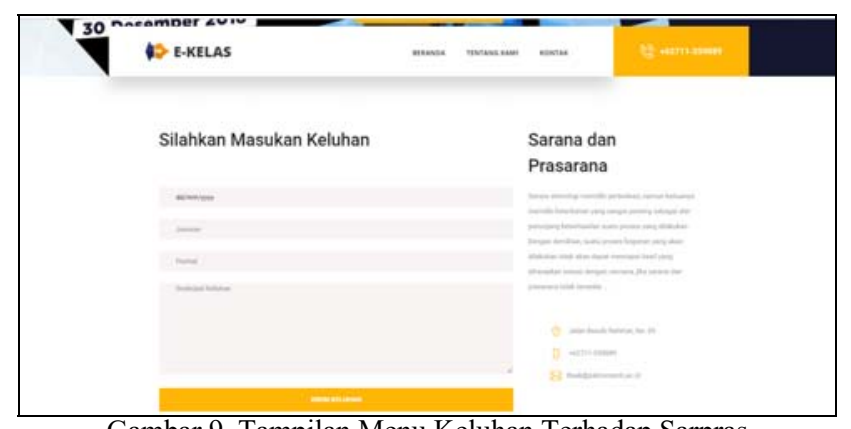

Gambar 9. Tampilan Menu Keluhan Terhadap Sarpras

\section{5) Tampilan Interface Login Admin}

Tampilan interface login admin adalah halaman yang menampilkan input login bagi admin yang mempunyai akses untuk masuk kehalaman admin. Halaman login admin berisi field seperti input username dan password. Menu tampilan untuk admin terlihat pada gambar 10 . 


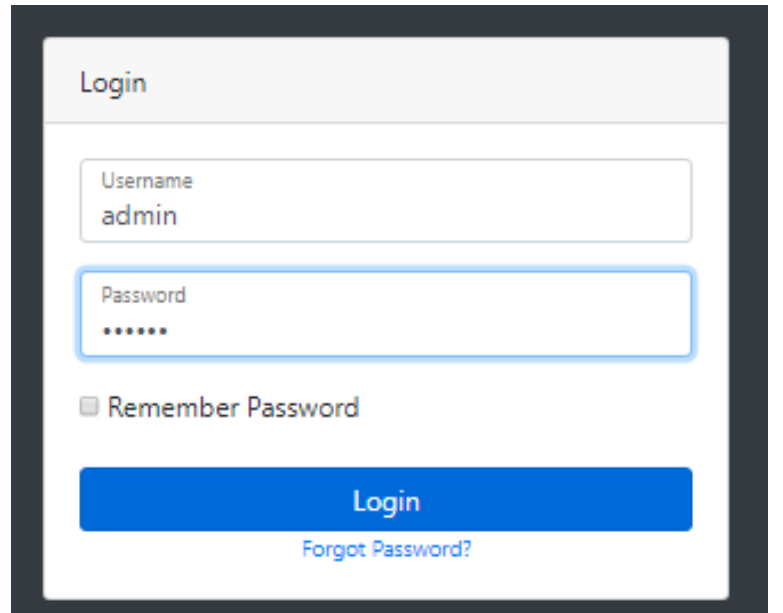

Gambar 10. Tampilan Admin

\section{6) Tampilan Dasboard Admin}

Tampilan dasboard admin adalah tampilan halaman utama dari admin. Halaman ini digunakan untuk mengetahui berapa banyak keluhan yang masuk dalam perhari. Tugas admin adalah memonitoring keluhan dan mengecek keluhan yang bersifat negatif. Keluhan yang bersifat negatif tidak akan diproses oleh admin. Keluhan-keluhan yang berhasil disaring akan dicetak dapat bentuk laporan yang nantinya akan diberikan kepada pimpinan. Menu tampilan dasboard terlihat pada gambar 11 .

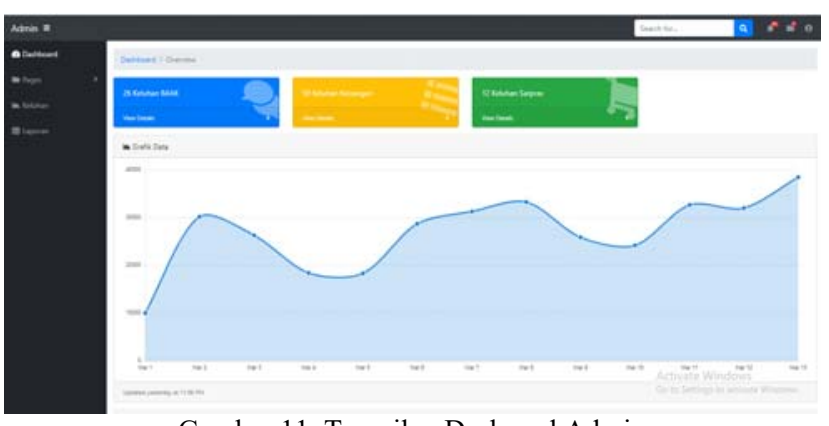

Gambar 11. Tampilan Dasboard Admin

\section{7) Tampilan Menu Keluhan}

Tampilan menu keluhan adalah tampilan yang memperlihatkan keluhan-keluhan dari mahasiswa yang diinputkan melalui aplikasi. Tampilan menu keluhan akan terlihat pada gambar 12 .

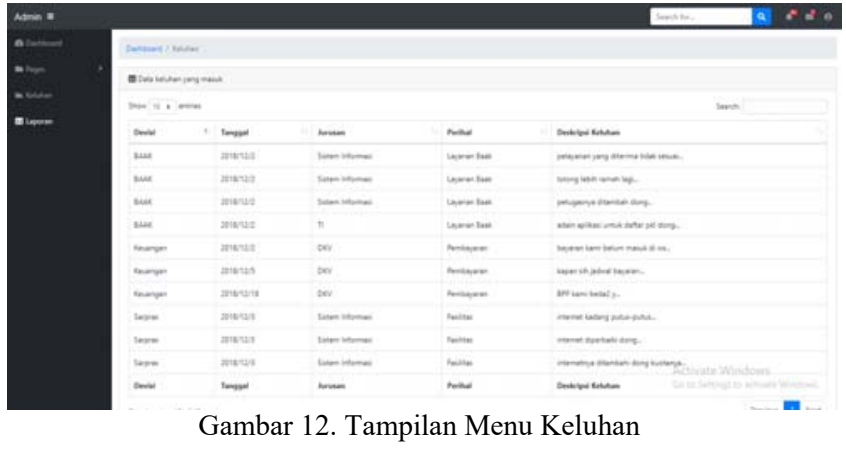

\section{PENUTUP}

\section{A. Kesimpulan}

Sistem pengaduan layanan akademik bagi mahasiswa menggunakan menggunakan responsive web desain mampu mempermudah mahasiswa dalam menyampaikan keluhan terhadap layanan akademik yang diterima. Sistem ini terdiri dari tiga menu yaitu layanan BAAK, layanan keuangan dan layanan Sarpras dimana mahasiswa dapat memberikan keluhannya terhadap masing-masing layanan. Print out dari keluhan mahasiswa ini adalah laporan yang akan diberikan kepada pimpinan untuk ditindak lanjuti.

\section{B. Saran}

Adapun saran yang akan diberikan oleh penulis.

- Aplikasi yang telah dibangun ini hendaknya terus digunakan oleh SPMI untuk lebih membantu dalam memonitoring kepuasan mahasiswa pada pelayanan suatu perguruan tinggi.

- Pengembangan aplikasi dimasa selanjutnya diharapkan adanya tambahan akses tidak hanya bagi mahasiswa melainkan bagi dosen yang mempunyai keluhan terhadap ketiga divisi. Diharapkan untuk melakukan pengembangan system aplikasi berbasis mobile.

- Aplikasi ini diharapkan agar dilakukan pemeliharaan dan disempurnakan lagi agar hasil yang diberikan system lebih bermanfaat lagi.

\section{DAFTAR PUSTAKA}

[1] S. Huda, "Sistem Informasi Keuangan Berbasis Desktop dengan Java Standard Edition \& MYSQL di Sekolah Tinggi Teknologi Nurul Jadid Paiton Probolinggo," Diambil dari: $\quad$ http://www. academia. edu/8328077/SISTEMINFORMASI_KEUANGAN_BERBAS IS_DESKTOP_DENGAN_JAVA_STANDARD _EDITION_and_MySQL_DI_SEKOLAH_TINGGI_TEKN 
OLOGI_NURUL_JADID_PAITO N_PROBOLINGGO, 2014.

[2] D. Kurniadi and A. Mulyani, "Implementasi Pengembangan Student Information Terminal (S-IT) Untuk Pelayanan Akademik Mahasiswa," Jurnal Algoritma, vol. 13, 2016.

[3] E. Indrayani, "Pengelolaan sistem informasi akademik perguruan tinggi berbasis Teknologi Informasi Dan Komunikasi (TIK)," Jurnal Penelitian Pendidikan, vol. 12, pp. 51-67, 2011.

[4] S. Indriyani and S. Mardiana, "Pengaruh Penanganan Keluhan (Complaint Handling) Terhadap Kepercayaan Dan Komitmen Mahasiswa Pada Perguruan Tinggi Swasta Di Bandar Lampung," Jurnal Bisnis Darmajaya, vol. 2, pp. 113, 2016.

[5] A. Baraja, "Implementasi Sistem Informasi Akademik Di Universitas Surakarta," Speed-Sentra Penelitian Engineering dan Edukasi, vol. 1, 2010.

[6] R. J. Rossheim, "Report on proposed American standard flowchart symbols for information processing," Communications of the ACM, vol. 6, pp. 599-604, 1963.

[7] O. U. Ariyanto, "Penerapan Teknologi Responsive Web Design dan Framework Bootstrap untuk Pembuatan Aplikasi Web Reservasi Dokter pada Klinik Pratama Mardi Lestari," Program Studi Teknik Informatika FTI-UKSW, 2016.

[8] I. Binanto, "Analisa Metode Classic Life Cycle (Waterfall) Untuk Pengembangan Perangkat Lunak Multimedia," Universitas Sanata Dharma, Yogyakarta, Indonesia, 2014.

[9] S. S. Haryanti, "Rancang Bangun Sistem Informasi ECommerce Untuk Usaha Fashion Studi Kasus Omah Mode Kudus," Speed-Sentra Penelitian Engineering dan Edukasi, vol. 3, 2011. 